\title{
South Atlantic overturning circulation at $24^{\circ} \mathrm{S}$
}

\author{
by Harry L. Bryden ${ }^{1,2}$, Brian A. King ${ }^{1}$ and Gerard D. McCarthy ${ }^{1}$
}

\begin{abstract}
To estimate the size of the meridional overturning circulation and the meridional heat and freshwater transports in the South Atlantic, we made a new transatlantic hydrographic section along $24^{\circ} \mathrm{S}$ in 2009 and we compare the resulting transports with those estimated for a historical section made in 1983. For the two sections, the overturning is estimated to be $21.5 \mathrm{~Sv}$ (2009) or $16.5 \mathrm{~Sv}$ (1983), the heat transport is northward at $0.7 \mathrm{PW}$ (2009) or $0.4 \mathrm{PW}$ (1983), and the freshwater transport is small but northward at $0.04 \mathrm{~Sv}$ (2009) or $0.17 \mathrm{~Sv}$ (1983). The differences in transports are primarily due to the different strengths of the southward Brazil Current transport during the occupation of the sections, $4.9 \mathrm{~Sv}$ (2009) or $12.3 \mathrm{~Sv}$ (1983). The freshwater transport associated with the meridional overturning circulation is estimated by two different methods for each of the two sections and is always southward ranging from $-0.09 \mathrm{~Sv}$ to $-0.34 \mathrm{~Sv}$ which means that the Atlantic meridional overturning circulation transports freshwater southward at $24^{\circ} \mathrm{S}$. On the basis of theoretical studies, such southward freshwater transport at the southern boundary of the Atlantic Ocean means that the present Atlantic circulation has multiple equilibrium states, and that the one it occupies at present may be unstable to a sufficiently large freshwater event.
\end{abstract}

\section{Introduction}

The freshwater balance for the Atlantic Ocean is a key issue for understanding the ocean's role in climate. Hydrological estimates suggest a strong net evaporation (Evaporation - Precipitation - Runoff) over the greater Atlantic basin between Bering Straits and its southern boundary at about $34^{\circ} \mathrm{S}$ (Baumgartner and Reichel, 1975; Wijffels et al., 1992). This strong net evaporation is widely considered to be a key reason why salty deep water is formed in the northern Atlantic. Ocean circulation based estimates of the mass and salt budgets for the greater Atlantic enclosed by the Bering Straits and a section across its southern boundary, however, indicate only a small net evaporation (Saunders and King, 1995; Weijer et al., 1999; McDonagh and King, 2005). These budgets have been based on WOCE transatlantic hydrographic sections A11 and A10 made along $45^{\circ} \mathrm{S}$ and $30^{\circ} \mathrm{S}$ latitudes, and analyses of these sections are complicated by energetic eddies and complex bottom topography. As a result, there is some confusion whether the hydrological estimates of the water budget agree or disagree with those based on ocean observations of mass and

1. National Oceanography Centre Southampton, Empress Dock, Southampton SO14 3ZH, United Kingdom.

2. Corresponding author.email: h.bryden@noc.soton.ac.uk 
$24^{\circ} \mathrm{S}$ Hydrographic Section

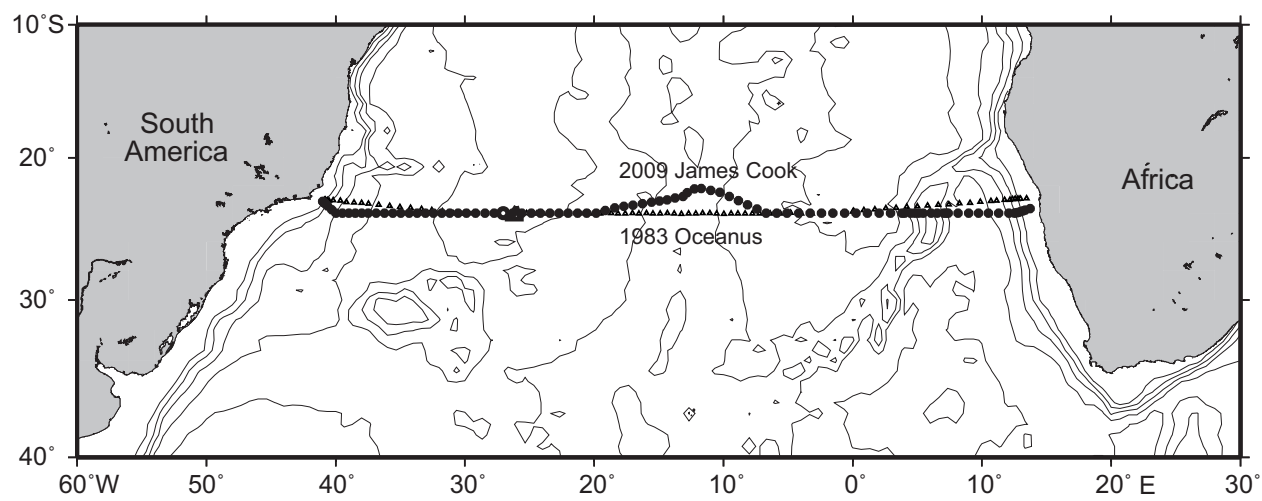

Figure 1. Location of $24^{\circ} \mathrm{S}$ transatlantic hydrographic stations in 2009 and 1983 . The locations of James Cook station 53 and Oceanus station 67 are indicated by larger symbols near $27^{\circ} \mathrm{W}$ to show the boundary between the western boundary and mid-ocean regions of the sections used for the circulations presented in Figures 3 and 4.

salt balances. To address the issues surrounding the overall water budget of the Atlantic basin, we made a new transatlantic hydrographic section along $24^{\circ} \mathrm{S}$ (King and Hamersley, 2010), a section that exhibits smaller eddy variability and simpler bottom topography than the A11 and A10 sections. Here we make estimates of the Atlantic mass and salt budgets based on this less complex section. We also make similar estimates for a 1983 section along $24^{\circ} \mathrm{S}$ (McCartney and Woodgate-Jones, 1991) to compare the circulation, mass and salt budgets for two $24^{\circ} \mathrm{S}$ sections and to understand the role of Brazil Current variability on the results.

\section{Observations}

In March-April 2009, RRS James Cook made a transatlantic hydrographic section along a nominal latitude of $24^{\circ} \mathrm{S}$ (Figs. 1 and 2, King and Hamersley, 2010). From the CTD measurements, we have estimated geostrophic velocity profiles, initially referenced to 1300 dbar based on Warren and Speer's (1991) analysis of the eastern basin circulation at $11^{\circ} \mathrm{S}$ and $24^{\circ} \mathrm{S}$. We then adjusted the profiles with a small uniform velocity of $-0.0005 \mathrm{~cm}$ $\mathrm{s}^{-1}$ so that there is no net meridional transport across $24^{\circ} \mathrm{S}$ once the southward wind-driven Ekman transport of $-4.6 \mathrm{~Sv}\left(1 \mathrm{~Sv}=1 \times 10^{6} \mathrm{~m}^{3} \mathrm{~s}^{-1}\right)$ is added to the geostrophic transport. The Ekman transport is based on NCEP wind stresses (http://iridl.ldeo.columbia.edu/) at

Figure 2. (a) Potential temperature section along $24^{\circ} \mathrm{S}$ in the South Atlantic in 2009; (b) Salinity section along $24^{\circ} \mathrm{S}$ in the South Atlantic in 2009. The location of station 53 separating the eastern and western circulations in Figure 3 is indicated. 
Potential Temperature RRS James Cook 2009 23 53
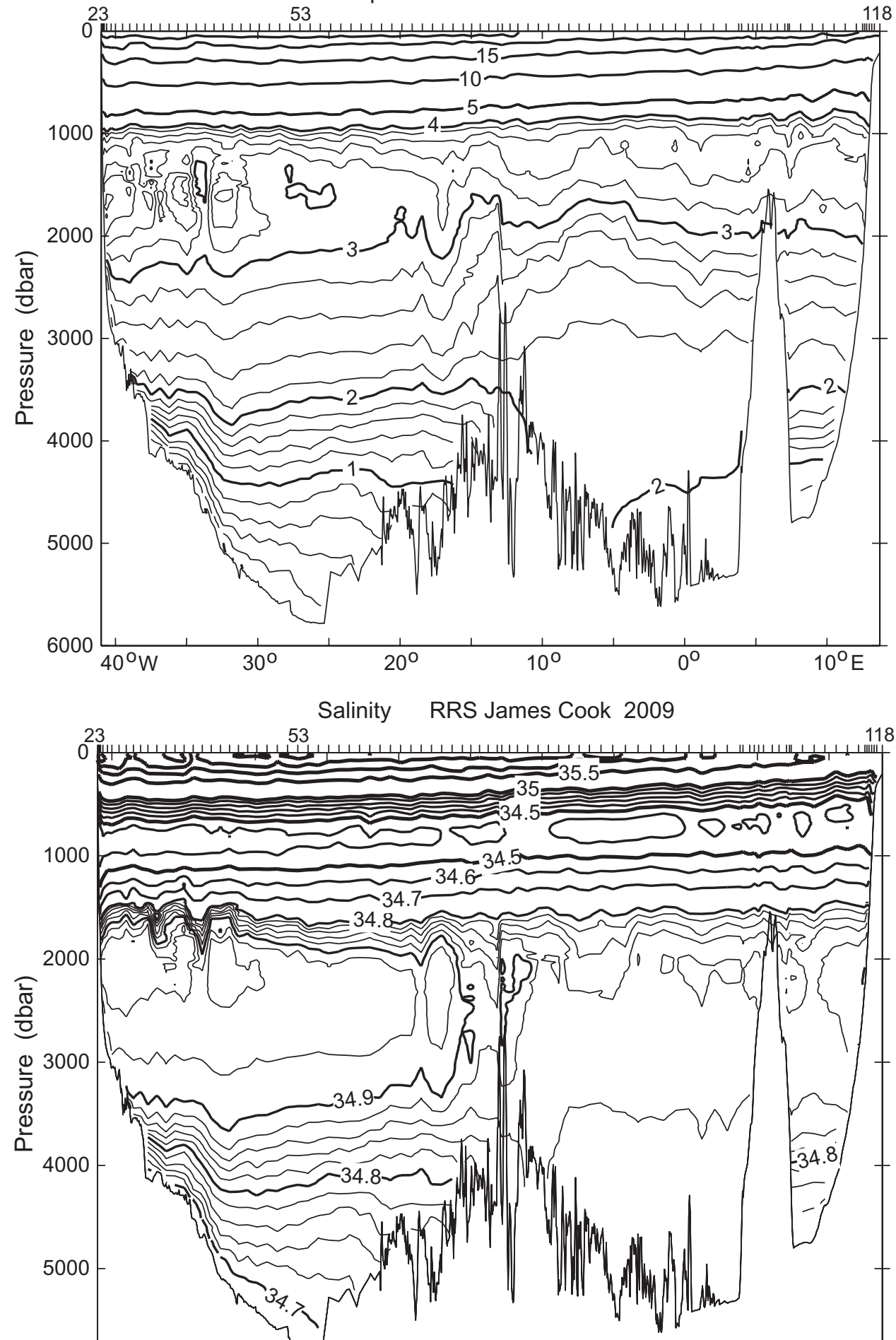
2009 James Cook $24^{\circ}$ S Atlantic Circulation

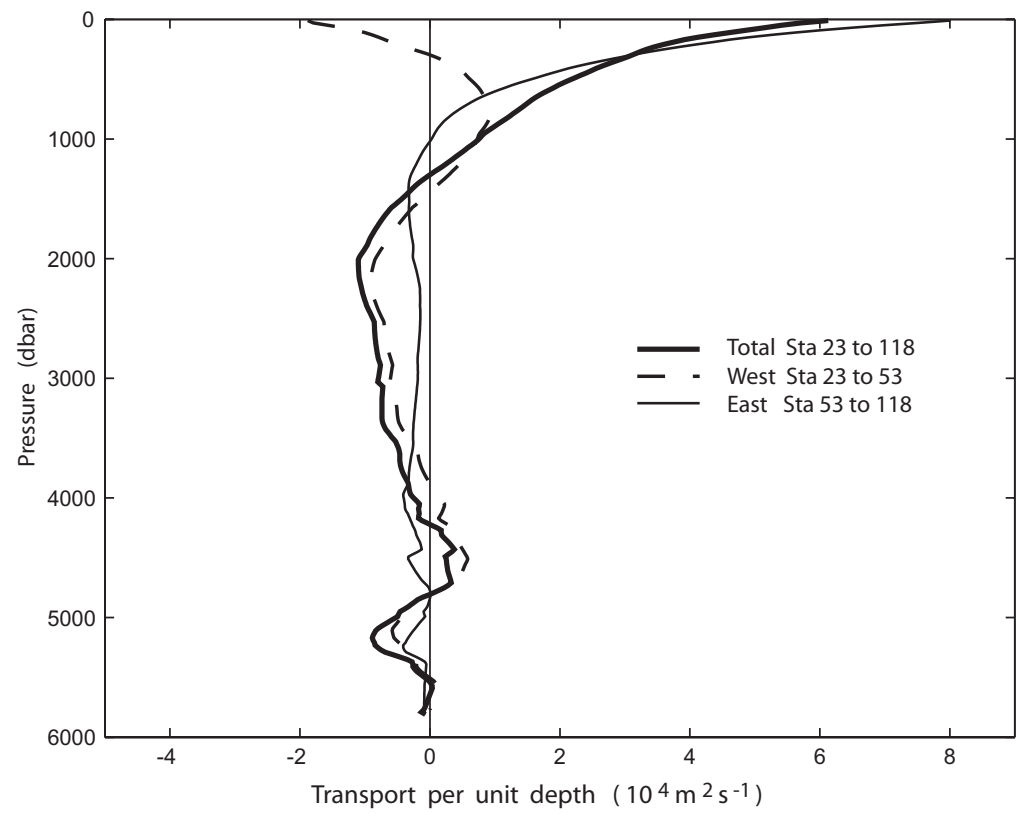

Figure 3. Meridional circulation across $24^{\circ} \mathrm{S}$ based on RRS James Cook hydrographic section in 2009. Transport per unit depth (northward velocity times zonal distance) is plotted for the western part of the section (dashed line), for the eastern part (light solid line), and for the total section (heavy solid line). The dividing station 53 near the deepest point west of the Mid Atlantic Ridge (shown on Figs. 1 and 2) is chosen so that the western boundary currents are all in the western part of the section. The southward flowing Brazil Current is notable in the upper $300 \mathrm{dbar}$ of the western section; northward flowing thermocline and intermediate waters are apparent in the eastern section. For the overall section, the depth of zero flow represents the depth of the meridional overturning circulation above which there is overall northward flow above and below which there is southward flow.

$23.8^{\circ} \mathrm{S}$ averaged for February-March when both the 2009 and 1983 sections were made. The resulting overall circulation exhibits northward geostrophic flow above 1300 dbar of 26.1 Sv, southward flows between 1300 and 4220 dbar and below $4800 \mathrm{dbar}$ of $-19.4 \mathrm{~Sv}$ and $-3.5 \mathrm{~Sv}$ respectively with a small amount of northward flow between 4220 and $4800 \mathrm{dbar}$ of $1.4 \mathrm{~Sv}$ (Fig. 3). The circulation is split into western and eastern regions (indicated by the location of station 53 on Fig. 1 and Fig. 2) so that some of the structure of the deep western boundary currents can be identified.

Adding the southward Ekman transport (which is effectively counter-balanced by the geostrophic flow in the top $80 \mathrm{~m}$ of the water column) to the geostrophic transport profile results in a net northward flow of waters above 1300 dbar of $21.5 \mathrm{~Sv}$ and a compensating southward flow of deeper water. Thus, for the 2009 section we estimate the meridional overturning circulation at $24^{\circ} \mathrm{S}$ to be $21.5 \mathrm{~Sv}$ and the depth of the overturning to be 
$1300 \mathrm{dbar}(1288 \mathrm{~m})$. For comparison, the overturning circulation at $26^{\circ} \mathrm{N}$ has been estimated from Rapid time series measurements to be $18.7 \mathrm{~Sv}$ with a depth of $1041 \mathrm{~m}$ (Cunningham et al., 2007).

To calculate the meridional heat and freshwater transports we follow the methodology in Bryden and Imawaki (2001) to split the circulation into horizontal (gyre), vertical (baroclinic) and barotropic components (Table 1). In terms of meridional heat transport, we assign the southward Ekman transport to have a temperature equal to the sea surface temperature (Wijffels et al., 1994) and consider it together with the zonally averaged geostrophic flow. The overturning circulation then transports $0.76 \mathrm{PW}$ of heat northward due to the net northward transport of $21.5 \mathrm{~Sv}$ of warmer upper layer waters balanced by the southward transport of $-21.5 \mathrm{~Sv}$ of colder deeper waters with an effective temperature difference overall of about $9^{\circ} \mathrm{C}$. There is also a horizontal (or gyre) heat transport principally associated with warm Brazil Current waters flowing southward and slightly colder mid-ocean upper thermocline waters flowing northward with no net mass transport and this contributes a southward horizontal heat transport of $-0.07 \mathrm{PW}$ concentrated in the upper $300 \mathrm{~m}$ of the ocean. Overall then the net northward heat transport across $24^{\circ} \mathrm{S}$ is $0.68 \mathrm{PW}$. This is about half of the northward heat transport at $26^{\circ} \mathrm{N}$ of $1.3 \mathrm{PW}$ (Johns et al., 2011).

In terms of meridional salinity and freshwater transports, we assign the southward Ekman transport to have a salinity equal to the sea-surface salinity and consider it with the zonal average geostrophic flow. The resultant northward flow of upper waters is saltier than the southward flow of deeper waters and hence there is a northward salinity transport associated with the meridional overturning circulation at $24^{\circ} \mathrm{S}$ of $4.6 \mathrm{~Sv}$ psu. ${ }^{3}$ The sign and magnitude of the overturning salinity transport at the southern boundary of the South Atlantic have important implications for the stability of the Atlantic overturning circulation (Drijfhout et al., 2011). As with heat transport, there is also a gyre component of the salinity transport associated with southward flowing saltier Brazil Current waters and northward flowing slightly fresher mid-ocean upper thermocline waters of $-4.3 \mathrm{~Sv}$ psu (Fig. 5), so this horizontal component virtually cancels the overturning salinity transport. The net northward salinity transport assuming no net meridional transport across $24^{\circ} \mathrm{S}$ then is $0.3 \mathrm{~Sv}$ psu. For the overall salt budget of the Atlantic basin bounded in the south by $24^{\circ} \mathrm{S}$ and in the north by Bering Straits, in addition to the salinity flux across $24^{\circ} \mathrm{S}$ we must consider the inflow through Bering Straits of $0.8 \mathrm{~Sv}$ at a salinity of 32.5 and the barotropic flow southward across $24^{\circ} \mathrm{S}$ at the section-averaged salinity of 34.864 . The barotropic southward flow across $24^{\circ} \mathrm{S}$ equals the Bering Straits transport minus the amount of net

3. The 2009 hydrographic section and subsequent analysis have been made with salinity as defined by UNESCO (1981). Such salinity is formally a ratio and has no units, but the salinity unit is often referred to as practical salinity unit (psu). When we estimate salinity flux here, we find it useful to express the salinity flux in units of Sv psu so it is clear that we have multiplied transport in Sv by salinity in psu. In 2010, a new definition of salinity was adopted where absolute salinity has units of parts per thousand (\%o) (IOC et al., 2010). Because this work was done prior to adoption of the new salinity, we have not used the new definition of salinity in the analysis and we avoid using $\% o$ as a unit for salinity. 
Table 1. Components of Heat and Salinity Transport across $24^{\circ} \mathrm{S}$ following definitions in Bryden and Imawaki (2001). Northward velocity, v, potential temperature, $\Theta$, and salinity $\mathrm{S}$ are separated into:

Section-averaged values,

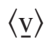

Zonally averaged baroclinic values,

Deviations from zonal averages,

\section{$\langle\mathrm{v}\rangle(\mathrm{z})$}

$\mathrm{v}^{\prime}(\mathrm{x}, \mathrm{z})$
$\langle\underline{\Theta}\rangle$

$\langle\Theta\rangle(\mathrm{z})$

$\Theta^{\prime}(\mathrm{x}, \mathrm{z})$

and

and

$\langle\mathrm{S}\rangle(\mathrm{z})$

and

where $\mathrm{v}=\langle\underline{\mathrm{v}}\rangle+\langle\mathrm{v}\rangle(\mathrm{z})+\mathrm{v}^{\prime}(\mathrm{x}, \mathrm{z}), \Theta=\langle\underline{\Theta}\rangle+\langle\Theta\rangle(\mathrm{z})+\Theta^{\prime}(\mathrm{x}, \mathrm{z})$ and $\mathrm{S}=\langle\underline{\mathrm{S}}\rangle+\langle\mathrm{S}\rangle(\mathrm{z})+$ $\mathrm{S}^{\prime}(\mathrm{x}, \mathrm{z})$. Mov is given as per definition in Drijfhout et al. (2011). L(z) is the width of the transoceanic section as a function of depth.

$\begin{array}{cc}2009 \text { James Cook } & 1983 \text { Oceanus } \\ \text { section } & \text { section }\end{array}$

Baroclinic component

\begin{tabular}{cll}
$\int \rho \mathrm{C}_{\mathrm{p}}\langle\mathrm{v}\rangle(\mathrm{z})\langle\Theta\rangle(\mathrm{z}) \mathrm{L}(\mathrm{z}) \mathrm{dz}$ & $0.76 \mathrm{PW}$ & $0.53 \mathrm{PW}$ \\
$\int\langle\mathrm{v}\rangle(\mathrm{z})\langle\mathrm{S}\rangle(\mathrm{z}) \mathrm{L}(\mathrm{z}) \mathrm{dz}$ & $4.60 \mathrm{~Sv} \mathrm{psu}$ & $3.25 \mathrm{~Sv} \mathrm{psu}$ \\
\hline Mov $=-(1 /\langle\underline{\mathrm{S}}\rangle) \int\langle\mathrm{v}\rangle(\mathrm{z})\langle\mathrm{S}\rangle(\mathrm{z}) \mathrm{L}(\mathrm{z}) \mathrm{dz}$ & $-0.13 \mathrm{~Sv}$ & $-0.09 \mathrm{~Sv}$ \\
\hline Horizontal component & & \\
\hline $\int \mathrm{dz} \int \mathrm{dx}\left\langle\rho \mathrm{C}_{\mathrm{p}} \mathrm{v}^{\prime} \Theta^{\prime}\right\rangle$ & $-0.07 \mathrm{PW}$ & $-0.14 \mathrm{PW}$ \\
$\int \mathrm{dz} \int \mathrm{dx}\left\langle\mathrm{v}^{\prime} \mathrm{S}^{\prime}\right\rangle$ & $-4.27 \mathrm{~Sv} \mathrm{psu}$ & $-7.29 \mathrm{~Sv} \mathrm{psu}$ \\
\hline Barotropic component & & \\
\hline Heat & $\rho \mathrm{C}_{\mathrm{p}}\langle\underline{\mathrm{v}}\rangle\langle\underline{\Theta}\rangle \int \mathrm{L}(\mathrm{z}) \mathrm{dz}$ & \\
\hline Bering Straits & $-0.8 \mathrm{~Sv} @ 0{ }^{\circ} \mathrm{C}$ & $-0.8 \mathrm{~Sv} @ 0^{\circ} \mathrm{C}$ \\
$24^{\circ} \mathrm{S}$ & $-0.755 \mathrm{~Sv} @ 4.191^{\circ} \mathrm{C}$ & $-0.63 \mathrm{~Sv} @ 4.236^{\circ} \mathrm{C}$ \\
Evaporation & $0.045 \mathrm{~Sv} @ 20^{\circ} \mathrm{C}$ & $0.17 \mathrm{~Sv} @ 20^{\circ} \mathrm{C}$ \\
\hline Difference & $-0.004 \mathrm{PW}$ & $-0.007 \mathrm{PW}$ \\
\hline Salt & $\langle\underline{\mathrm{v}}\rangle\langle\underline{\mathrm{S}}\rangle \int \mathrm{L}(\mathrm{z}) \mathrm{dz}$ & \\
\hline Bering Straits & $-0.8 \mathrm{~Sv} @ 32.5$ & $-0.8 \mathrm{~Sv} @ 32.5$ \\
$24^{\circ} \mathrm{S}$ & $-0.755 \mathrm{~Sv} @ 34.864$ & $-0.63 \mathrm{~Sv} @ 34.869$ \\
Evaporation & $0.045 \mathrm{~Sv} @ 0$ & $0.17 \mathrm{~Sv} @ 0$ \\
\hline Difference & $-0.32 \mathrm{~Sv} \mathrm{psu}$ & $4.03 \mathrm{~Sv} \mathrm{psu}$ \\
\hline \hline
\end{tabular}

For Atlantic Basin bounded by Bering Straits, $24^{\circ} \mathrm{S}$, America and Africa-Europe-Asia

\begin{tabular}{lll}
\hline & $\begin{array}{c}2009 \text { James Cook } \\
\text { section }\end{array}$ & $\begin{array}{c}1983 \text { Oceanus } \\
\text { section }\end{array}$ \\
\hline Ocean heat transport convergence & $0.68 \mathrm{PW}$ & $0.38 \mathrm{PW}$ \\
\hline Net evaporation & $0.04 \mathrm{~Sv}$ & $0.17 \mathrm{~Sv}$ \\
\hline
\end{tabular}

Mass and salt transports sum to 0 :

$24^{\circ} \mathrm{S}$ Mass Transport - Bering Straits = Evaporation for each section

Baroclinic + Horizontal + Barotropic Salinity Transport $=0$ for each section 
1983 Oceanus $24^{\circ} \mathrm{S}$ Atlantic Circulation

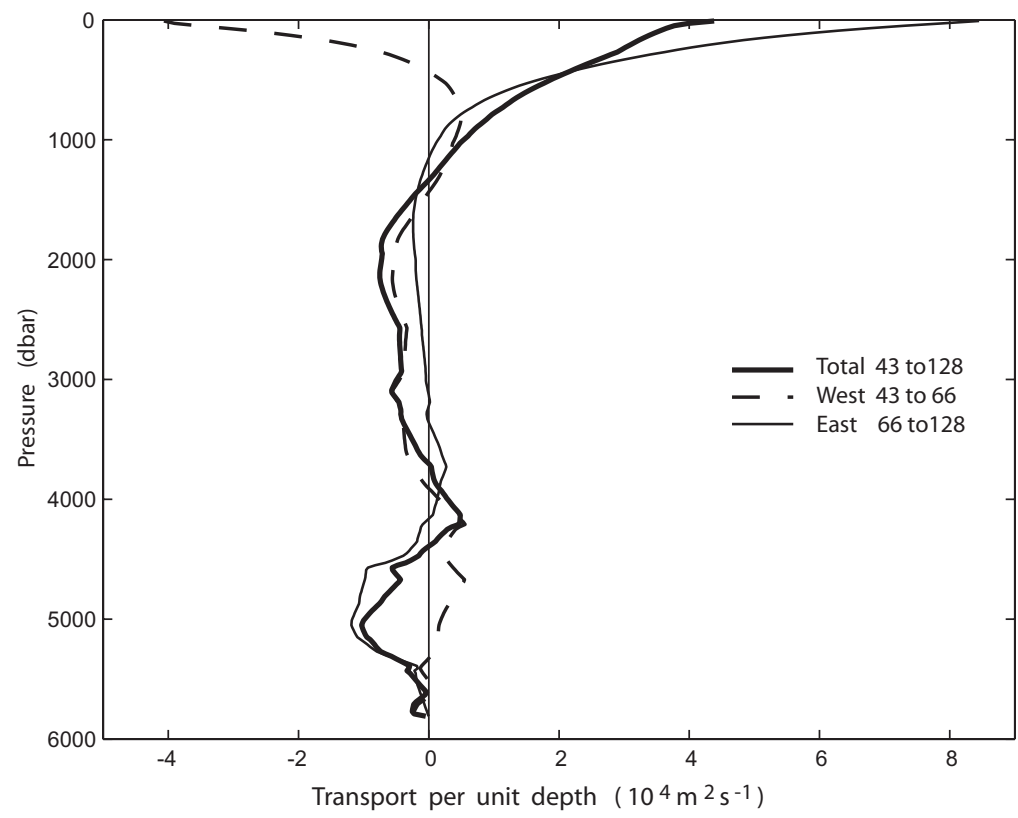

Figure 4. Meridional circulation across $24^{\circ} \mathrm{S}$ based on $R / V$ Oceanus hydrographic section in 1983. Transport per unit depth (northward velocity times zonal distance) is plotted for the western part of the section (dashed line), for the eastern part (light solid line), and for the total section (heavy solid line). The dividing station 67 near the deepest point west of the Mid Atlantic Ridge (shown on Fig. 1 ) is chosen so that the western boundary currents are all in the western part of the section. The southward flowing Brazil Current is notable in the upper 300 dbar of the western section; northward flowing thermocline and intermediate waters are apparent in the eastern section. For the overall section, the depth of zero flow represents the depth of the meridional overturning circulation above which there is overall northward flow and below which there is southward flow.

evaporation over the Atlantic basin. Conserving mass and salt, we estimate a net evaporation of $0.04 \mathrm{~Sv}$ is required for the Atlantic Ocean between Bering Straits and the $200924^{\circ} \mathrm{S}$ section (Table 1).

We have repeated the calculations using the R/V Oceanus 133 section (station positions shown in Fig. 1) along $24^{\circ} \mathrm{S}$ taken in February-March 1983 (McCartney and WoodgateJones, 1991). For this section a uniform velocity of $0.012 \mathrm{~cm} \mathrm{~s}^{-1}$ was added to the geostrophic velocity field using an initial reference level of $1300 \mathrm{dbar}$ to make the overall geostrophic transport balance the southward Ekman transport of $-4.6 \mathrm{~Sv}$. The geostrophic flow exhibits northward flow of 21.0 Sv above 1340 dbar, a southward flow of $-11.1 \mathrm{~Sv}$ between 1340 and 3700 dbar, a northward flow of $1.6 \mathrm{~Sv}$ between 3700 and $4400 \mathrm{dbar}$ and a southward flow of $-7.0 \mathrm{~Sv}$ below $4400 \mathrm{dbar}$ (Fig. 4). The overturning circulation combining the geostrophic and Ekman flows has a net northward transport of $16.4 \mathrm{~Sv}$ 
above a depth of $1320 \mathrm{~m}$ with a compensating southward transport of deeper water. In terms of heat transport where the Ekman transport is assigned a temperature equal to sea surface temperature, the overturning circulation transports $0.53 \mathrm{PW}$ of heat northward due to net northward transport of $16.4 \mathrm{~Sv}$ of warmer upper waters compensated by a southward transport of colder deeper waters with an effective temperature difference of about $8^{\circ} \mathrm{C}$. For the Oceanus 1983 section, there is also a southward gyre (horizontal) heat transport associated principally with warm Brazil Current waters flowing southward and slightly colder mid-ocean upper thermocline waters flowing northward (with no net mass transport) and this gyre circulation contributes a southward heat transport of $-0.14 \mathrm{PW}$ concentrated in the upper $500 \mathrm{~m}$ of the water column. Overall then we estimate the northward heat transport across the Oceanus $24^{\circ} \mathrm{S}$ section to be $0.38 \mathrm{PW}$ (Table 1).

In terms of salinity and freshwater transports for the 1983 Oceanus $24^{\circ} \mathrm{S}$ section, there is a northward salinity transport associated with the overturning circulation including the Ekman transport at the sea surface salinity of $3.25 \mathrm{~Sv}$ psu. Again the overturning salinity transport is northward. There is a gyre component to the salinity transport associated with saltier Brazil Current waters flowing southward balanced by relatively fresher mid-ocean waters flowing northward (Fig. 5) and this gyre salinity transport is southward amounting to $-7.3 \mathrm{~Sv}$ psu. Overall, the circulation with no net mass transport across the Oceanus $24^{\circ} \mathrm{S}$ section transports salinity southward at a rate of $-4.0 \mathrm{~Sv}$ psu. Considering the mass balance for the region enclosed by Bering Straits, $24^{\circ} \mathrm{S}$ and the continents of Africa, America, Asia and Europe where there is an inflow through Bering Straits of $0.8 \mathrm{~Sv}$ at a salinity of 32.5, we estimate a net evaporation of $0.17 \mathrm{~Sv}$ is required within the AtlanticArctic basin north of $24^{\circ} \mathrm{S}$ to balance mass and salinity fluxes across the boundaries of the basin for the $198324^{\circ} \mathrm{S}$ section (Table 1).

The James Cook 2009 circulation and Oceanus 1983 circulation differ principally in the strength of the Brazil Current at the time the sections were made. For the 2009 James Cook section, the Brazil Current was confined close to the coast and had a maximum southward transport referenced to the bottom of $-4.9 \mathrm{~Sv}$. For the 1983 Oceanus section, the Brazil Current was $-12.3 \mathrm{~Sv}$, or $7.4 \mathrm{~Sv}$ larger than the 2009 section. The mid-ocean circulations estimated from geostrophic transports eastward from the eastern edge of the Brazil Current to the coast of Africa above $1200 \mathrm{~m}$ depth are similar, 28.9 Sv for 2009 and $29.8 \mathrm{~Sv}$ for 1983. In terms of the procedures used here to define the circulation, the stronger 1983 Brazil Current results in less net northward upper layer flow so the overturning and associated heat transport are reduced relative to the 2009 circulation with a weaker Brazil Current. Also, the stronger Brazil Current in 1983 produces stronger southward gyre heat and salinity transports in 1983 compared with 2009.

\section{Concept of a subtropical gyre}

For a wind-driven subtropical gyre at a latitude of $24^{\circ} \mathrm{S}$, one expects poleward Ekman transport in the surface layer, equatorward mid-ocean circulation driven by the wind stress curl and a poleward flowing western boundary current that balances the mid-ocean flow. In 
$24^{\circ} \mathrm{S}$ Horizontal Eddy Salt Flux

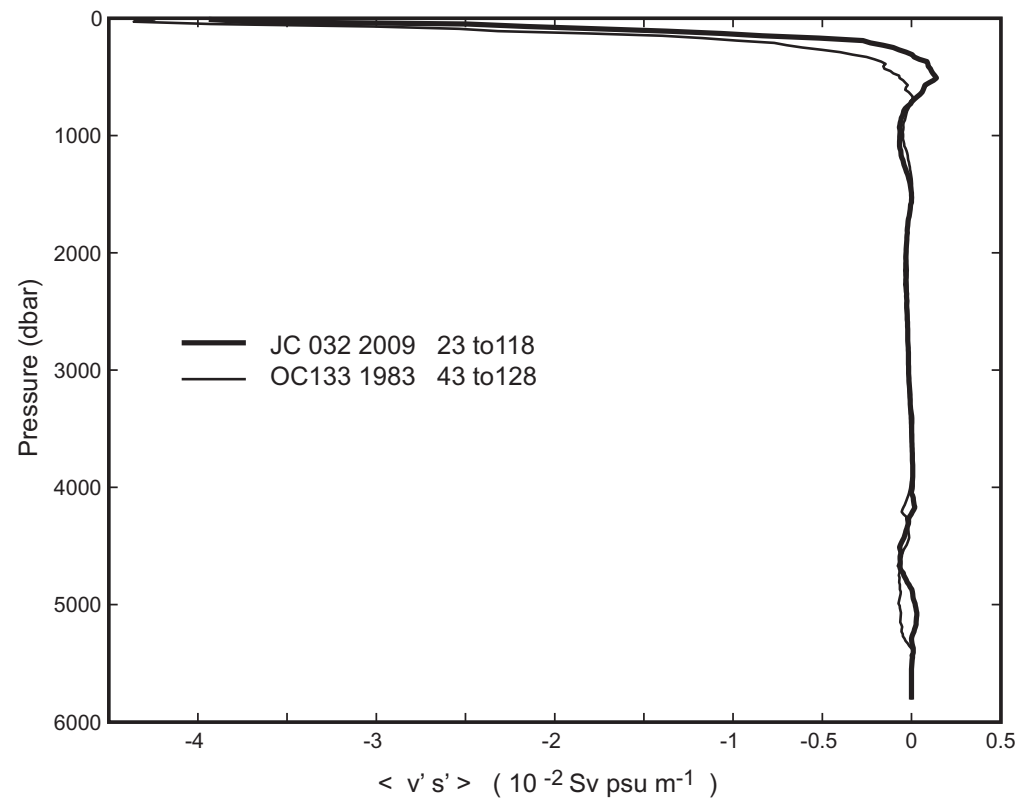

Figure 5. Profile of northward salinity transport associated with horizontal (either gyre or eddy) variations at each depth for the 2009 James Cook (heavy line) and 1983 Oceanus (light solid line) sections. Similar profiles occur for horizontal heat transport. The southward transport above $500 \mathrm{dbar}$ is due to southward flow of saltier Brazil Current and saltier intermediate waters in the west and less salty northward flow of thermocline and intermediate waters in mid-ocean.

terms of the water budget, one expects net evaporation equatorward of $24^{\circ} \mathrm{S}$ and net precipitation poleward of $24^{\circ} \mathrm{S}$ so there should be a poleward salinity flux across $24^{\circ} \mathrm{S}$, implying an equatorward freshwater transport that returns the freshwater from the region of precipitation to the region of evaporation. Such a concept of a subtropical gyre is present in the circulations for both the James Cook and Oceanus sections along $24^{\circ} \mathrm{S}$ : the poleward Ekman and Brazil Current transports are saltier than their compensating equatorward flows. Attempting to separate out the gyre component for freshwater transport by balancing the southward Brazil Current transport with northward gyre transport over similar depths and by balancing the southward Ekman transport with a uniform northward transport over the full depth and width of the section results in an estimate of the gyre southward salinity transports of $-11.8 \mathrm{~Sv}$ psu and $-14.4 \mathrm{~Sv}$ psu for the James Cook and Oceanus sections respectively; equivalently, northward freshwater transports across $24^{\circ} \mathrm{S}$ of $0.30 \mathrm{~Sv}$ and $0.40 \mathrm{~Sv}$ are required to balance the salt budget of the gyre circulation for the James Cook and Oceanus sections (Table 2). For comparison, the poleward salinity flux across $24^{\circ} \mathrm{N}$ in the subtropical gyre of the North Pacific which has no deep overturning is $5.5 \mathrm{~Sv}$ psu, implying a net precipitation north of $24^{\circ} \mathrm{N}$ of $0.21 \mathrm{~Sv}$ (Bryden et al., 1991). Thus the South 
Table 2 Salinity transport across $24^{\circ} \mathrm{S}$ separated into gyre and overturning components.

\begin{tabular}{|c|c|c|}
\hline & $\begin{array}{l}2009 \text { James Cook } \\
\text { section }\end{array}$ & $\begin{array}{l}1983 \text { Oceanus } \\
\text { section }\end{array}$ \\
\hline Section-average salinity & 34.864 & 34.869 \\
\hline Surface salinity & 36.460 & 36.382 \\
\hline Ekman transport & $4.6 \mathrm{~Sv}$ & $4.6 \mathrm{~Sv}$ \\
\hline Brazil Current transport & $-4.9 \mathrm{~Sv}$ & $-12.2 \mathrm{~Sv}$ \\
\hline \multicolumn{3}{|l|}{$\begin{array}{l}\text { Components of salinity flux for no net mass } \\
\text { transport }\end{array}$} \\
\hline $\begin{array}{l}\text { Gyre circulation: Ekman transport } \times \text { (surface } \\
\text { salinity }- \text { section-average salinity) }\end{array}$ & $-7.52 \mathrm{~Sv}$ psu & $-7.13 \mathrm{~Sv}$ psu \\
\hline Gyre circulation: horizontal salinity transport & $-4.27 \mathrm{~Sv}$ psu & $-7.28 \mathrm{~Sv}$ psu \\
\hline Total gyre circulation & $-11.79 \mathrm{~Sv}$ psu & $-14.42 \mathrm{~Sv}$ psu \\
\hline $\begin{array}{l}\text { Overturning circulation (excluding Ekman), no } \\
\text { net mass transport }\end{array}$ & $12.12 \mathrm{~Sv}$ psu & $10.38 \mathrm{~Sv}$ psu \\
\hline Mov $=-(1 /\langle\underline{S}\rangle) \times$ overturning salinity flux & $-0.34 \mathrm{~Sv}$ & $-0.29 \mathrm{~Sv}$ \\
\hline
\end{tabular}

Atlantic subtropical gyre at $24^{\circ} \mathrm{S}$ appears to be consistent with the standard concept of poleward salinity transport and equatorward freshwater transport returning water from the subpolar region of net precipitation to the tropical region of net evaporation.

\section{Concept of the Atlantic meridional overturning circulation}

The Atlantic overturning circulation consists of warm upper level waters flowing northward, becoming colder and denser and eventually transforming into cold dense deep waters that return southward at depth throughout the Atlantic. The reason that deep water is formed in the Atlantic is widely thought to be due to the higher salinity of the Atlantic associated with the large amount of net evaporation over the Atlantic basin: in this traditional argument, relatively fresh surface and intermediate waters enter the Atlantic across its southern boundary, flow northward and become saltier due to mixing with waters that have become salty due to high evaporation in the tropics and subtropics like Mediterranean water and these saltier waters eventually lead to the formation of North Atlantic Deep Waters. Using the $24^{\circ} \mathrm{S}$ section, we quantify the salt budget for the Atlantic overturning circulation here and show that this traditional argument is not correct and that in fact the waters flowing northward across $24^{\circ} \mathrm{S}$ are already salty enough to form the North Atlantic Deep Waters that return southward across $24^{\circ} \mathrm{S}$.

Removing the gyre circulation including Ekman transport, western boundary current and mid-ocean recirculation, we have the overturning circulation at $24^{\circ} \mathrm{S}$ as estimated earlier of 26.1 Sv for the James Cook 2009 section and 21.0 Sv for the Oceanus 1983 section. This overturning circulation with no net mass transport and without the effects of 
Ekman transport (which has been included in the gyre transport) carries a northward salinity transport of 12.1 Sv psu (2009) or 10.4 Sv psu (1983). For comparison, the amount of northward salinity transport across $24^{\circ} \mathrm{S}$ required to raise the salinity of the Bering Straits inflow of $0.8 \mathrm{~Sv}$ from $32.5^{\circ}$ to the section averaged salinity of 34.865 at $24^{\circ} \mathrm{S}$ is $1.9 \mathrm{~Sv}$ psu. Thus, the northward salinity transport associated with the overturning circulation across $24^{\circ} \mathrm{S}$ is much more than required to raise the Bering Straits salinity (Table 2). The northward overturning salinity transport then implies there is actually a sizeable net precipitation required to maintain the overturning circulation in the Atlantic Ocean north of $24^{\circ} \mathrm{S}$, a net precipitation of $0.34 \mathrm{~Sv}$ (2009) or $0.29 \mathrm{~Sv}$ (1983). (Remember the gyre salinity transport is southwards so overall there is a small net evaporation needed north of $24^{\circ} \mathrm{S}$, but here we are trying to separate the gyre and overturning components.) In a sense there is enough salty water entering the South Atlantic from the south to form high salinity North Atlantic Deep Water (NADW). There is no need for large amounts of evaporation over the North Atlantic to make NADW because the inputs of surface and intermediate waters into the southern Atlantic already have high enough salinity to make NADW.

To quantify the amounts of high salinity thermocline water and low salinity intermediate waters, we estimate the amount of northward flowing waters with salinity greater than 35.0 (upper thermocline water, surface to $380 \mathrm{dbar}$ ) and with salinity less than 34.68 (intermediate water, 520 to 1300 dbar). For the James Cook 2009 section, there are northward transports of $10.6 \mathrm{~Sv}$ of salty thermocline water and $8.1 \mathrm{~Sv}$ of low salinity intermediate water; for the Oceanus 1983 section there are northward transports of $8.0 \mathrm{~Sv}$ of salty thermocline water and $5.7 \mathrm{~Sv}$ of low salinity intermediate water. For both sections the amount of northward transport of salty thermocline waters is larger than that of low salinity intermediate waters. It is unclear whether the difference in proportions is due to a change over time in contributions of Indian Ocean leakage (McCarthy et al., 2011) or to the stronger southward transport in the Brazil Current recirculating the upper thermocline waters in 1983. Overall for both 1983 and 2009 sections, the northward flow of upper thermocline waters with salinities above 35 across $24^{\circ} \mathrm{S}$ represents the major source of salinity for the eventual formation of North Atlantic Deep Water.

Where do these high salinity thermocline waters come from? There is no water in Drake Passage with salinity greater than 35 , so it is unlikely that the salty thermocline waters at $24^{\circ} \mathrm{S}$ in the Atlantic come directly from the Pacific. In the Indian Ocean, waters above $500 \mathrm{~m}$ depth have salinities greater than 35 and in the Agulhas Current at $32^{\circ} \mathrm{S}$ the surface waters, 0 to $300 \mathrm{dbar}$, flowing southward out of the Indian Ocean have salinities typically between 35.5 and 35.6. Thus, the origin of the high salinity thermocline waters flowing northward across $24^{\circ} \mathrm{S}$ in the South Atlantic is likely to be in the Indian Ocean. We estimate that $55 \%$ of the source waters for the eventual formation of North Atlantic Deep water are relatively high salinity upper thermocline waters observed at $24^{\circ} \mathrm{S}$ that have come from the Indian Ocean via the Agulhas Current and 45\% of the source waters are low salinity intermediate waters. These intermediate waters may have come from the Pacific 
Ocean via Drake Passage, from the Indian Ocean via the Agulhas Current, or may have been formed locally in the South Atlantic sector of the Southern Ocean.

\section{Agulhas leakage}

Time varying leakage of Agulhas waters from the Indian Ocean into the South Atlantic Ocean has been suggested as a trigger for changes in the Atlantic meridional overturning circulation on decadal (Biastoch et al., 2008) to centennial (Peeters et al., 2004) time scales. More high salinity waters entering the Atlantic from the Indian Ocean arguably enhance the ultimate formation of high salinity North Atlantic Deep water. The mechanism of Agulhas leakage is usually envisaged to be a set of Agulhas rings enclosing high salinity Indian Ocean waters breaking off from the Agulhas Retroflection, entering the South Atlantic and propagating westward and northward (Beal et al., 2011). At $24^{\circ} \mathrm{S}$, the direct effect of such Agulhas rings is small: McCartney and Woodgate-Jones (1991) did observe a deep reaching anticyclonic eddy on the $24^{\circ} \mathrm{S}$ section in 1983 whose source they attributed to an Agulhas ring, but they determined that the overall transport associated with this large ring was small compared with the transport associated with the large-scale meridional circulation across $24^{\circ} \mathrm{S}$. Thus, at $24^{\circ} \mathrm{S}$ it is likely that the salinity effects of Agulhas rings have already been mixed into the ambient waters and effectively absorbed into the large-scale circulation. Analyses of southern sections like A10 at $30^{\circ} \mathrm{S}$ and $\mathrm{A} 11$ at $45^{\circ} \mathrm{S}$ are complicated by the presence of Agulhas rings and of large eddies near the Brazil Current/Falklands Current Confluence, and accounting for their northward salinity flux is problematic. Again we would argue that the $24^{\circ} \mathrm{S}$ transatlantic section is cleaner with respect to the effects of Agulhas rings and Confluence eddies on the salt and freshwater balances on the Atlantic basin because the effects of such rings and eddies have already been mixed into the large-scale circulation and do not have to be accounted for separately.

\section{Freshwater transport and stability of the meridional overturning circulation}

Climate models by and large suggest that the Atlantic and Arctic Ocean between the southern boundary at $34^{\circ} \mathrm{S}$ and the Bering Straits is a region of large net evaporation (Drijfhout et al., 2011). Water budget estimates (e.g. Baumgartner and Reichel, 1975; Wijffels et al., 1992) agree that the Atlantic is an evaporative basin. It is not well appreciated that ocean observations strongly suggest that the overall Atlantic net evaporation is very small. Saunders and King (1995) used the WOCE A11 section across the southern boundary of the South Atlantic at about $45^{\circ} \mathrm{S}$ to estimate a net northward oceanic salinity transport of $0.8 \mathrm{~Sv}$ psu suggesting a small (not significant) net precipitation of $0.02 \mathrm{~Sv}$ over the Atlantic between $45^{\circ} \mathrm{S}$ and Bering Straits. Weijer et al. (1999) made a similar estimate for the WOCE A10 section along $30^{\circ} \mathrm{S}$ and concluded that the "overturning circulation effectively exports freshwater from the Atlantic and is unable to supply freshwater to compensate for the excess evaporation." McDonagh and King (2005) reanalyzed both $\mathrm{A} 10$ and $\mathrm{A} 11$ sections to estimate a small overall net evaporation for the 
Atlantic basin of about $0.1 \mathrm{~Sv}$. Both the A11 and A10 transatlantic sections are complicated to analyze and modelers have tended to ignore these results in preference to more complete model information (e.g., discussion in Drifjhout et al., 2011). Here we analyze the less complex $24^{\circ} \mathrm{S}$ section that arguably poses fewer bottom topography issues and is quieter in terms of eddy variability than the A10 and A11 sections. Salinity flux for the circulation across the 2009 James Cook section suggests there is a small net evaporation over the Atlantic basin between $24^{\circ} \mathrm{S}$ and Bering Straits of $0.04 \mathrm{~Sv}$. Similar calculation for the 1983 Oceanus section suggests a net evaporation over the Atlantic basin of $0.17 \mathrm{~Sv}$. As a small net precipitation is expected between $24^{\circ} \mathrm{S}$ and the A11 section, this analysis supports earlier conclusions by Saunders and King (1995), Weijer et al. (1999) and McDonagh and King (2005) that there is little net evaporation over the Atlantic basin between its southern boundary and Bering Straits.

The salinity flux across the southern boundary of the Atlantic Ocean, or the freshwater balance for the Atlantic basin between $34^{\circ} \mathrm{S}$ and Bering Straits, is an important consideration for the Atlantic meridional overturning circulation. Rahmstorf (1996) first linked the direction of the freshwater transport to the stability of the Atlantic overturning circulation and argued that if the freshwater transport is southward then the overturning circulation may be close to a bifurcation point. Dijkstra (2007) showed that the sign of the overturning salinity flux, which he called Mov salt transport

$$
\operatorname{Mov}=-(1 /\langle\underline{S}\rangle) \int\langle\mathrm{v}\rangle(\mathrm{z})\langle\mathrm{S}\rangle(\mathrm{z}) \mathrm{L}(\mathrm{z}) \mathrm{dz}
$$

(where $\mathrm{v}$ is northward velocity, $\mathrm{S}$ is salinity, $\mathrm{L}$ is the width of the zonal section, $\mathrm{z}$ is depth, brackets indicate zonal average and underscore represents vertical average), determines whether the overturning circulation is stable or whether it exhibits multiple equilibria in some classes of models. According to Dijkstra's analysis, for a northward salinity flux across the southern boundary, equivalent to a net precipitation over the Atlantic basin, the Atlantic meridional overturning circulation has multiple equilibria. Ocean observations indicate that the salinity flux at the southern boundary is quite small, probably slightly southward but very close to zero, indicating that recovery from a freshwater forcing event would be extended. Moreover, in a changing climate where the hydrological cycle is expected to become larger (more evaporation in the tropics and more precipitation in subpolar and polar regions), it is possible that the small net evaporation over the Atlantic basin may switch to become a net precipitation, making shutdown in the overturning circulation theoretically more likely.

The Mov salt transport emphasised by Drijfhout et al. (2011) and Dijkstra (2007) is slightly more restrictive than the overall water balance for the Atlantic basin in that it emphasises the salinity flux contribution by the overturning circulation only. Furthermore, the term Mov salt transport is confusing in that it is the negative salinity transport by the overturning circulation divided by the section average salinity so that it is effectively the 
freshwater transport associated with the overturning circulation. We have calculated the overturning Mov salt transport in two ways: first for the overturning circulation including the Ekman transport (Table 1); and secondly for the overturning circulation where we have removed the gyre circulation including the local wind-driven Ekman transport (Table 2). For the $24^{\circ} \mathrm{S}$ section, the salinity flux of the overturning circulation including the local Ekman transport is northward both for the 2009 James Cook section (4.6 Sv psu,) and also for the 1983 Oceanus section (3.3 Sv psu). In terms of the definitions by Drijfhout et al. (2011), Mov is the freshwater transport across $24^{\circ} \mathrm{S}$ associated with the meriional overturning circulation, it is southward, $-0.13 \mathrm{~Sv}$ for James Cook section and $-0.09 \mathrm{~Sv}$ for Oceanus, indicating a net input of freshwater north of $24^{\circ} \mathrm{S}$ is required to maintain the salinity structure of the overturning circulation. Because of model emphasis on Mov salt transport of the non-local overturning circulation we tried to separate out the gyre and overturning components of the circulation at $24^{\circ} \mathrm{S}$. The separation may be controversial in its details, but the essence is to estimate the salinity flux contribution of the wind-driven subtropical gyre (Ekman transport, poleward flowing western boundary current and equatorward mid-ocean thermocline flow) which in general should be poleward and remove it from the overall salinity flux so that the sign of the critical salinity flux contribution from the overturning circulation (northward flow of upper waters and southward flow of deep waters) can be isolated. For the overturning circulation without the effects of the local wind-driven Ekman and gyre transports (Table 2), the salinity flux is northward amounting to $12.1 \mathrm{~Sv}$ psu (2009) and $10.4 \mathrm{~Sv}$ psu (1983), equivalent to southward freshwater transports of $-0.34 \mathrm{~Sv}$ (2009) and $-0.29 \mathrm{~Sv}$ (1983). Thus the Mov salt transport is clearly southward for either method and for either the 2009 or 1983 section, ranging from $-0.09 \mathrm{~Sv}$ to $-0.34 \mathrm{~Sv}$.

Dijkstra (2007) argued that when the Mov is negative a freshwater anomaly over the northern Atlantic that reduced deep water formation and hence the overturning circulation would reduce the southward freshwater transport across the southern boundary of the Atlantic and accentuate the freshwater anomaly making recovery to the original overturning circulation impossible. Thus when the Mov is negative, a freshwater anomaly could shut down the Atlantic meridional overturning circulation permanently. This is the argument for multiple equilibria: there is an overturning circulation under present conditions but a small, limited-time freshwater anomaly could send the circulation to a nearby equilibrium state with no overturning. This is consistent with the results of Marsh et al. (2007) who found that when Agulhas leakage dominated over evaporative controls on Atlantic salinity, as the hydrographic data suggests is the case here, MOC collapse is more likely.

There is clear observational evidence that Mov is negative at the southern boundary of the Atlantic. Saunders and King (1995) effectively first showed that the overturning circulation carries freshwater out of the Atlantic at its southern boundary at $45^{\circ} \mathrm{S}$. Here we analyse the $24^{\circ} \mathrm{S}$ transatlantic sections in 2009 and 1983 to quantify Mov directly in two different definitions, to confirm that the Mov salt transport is indeed negative and to show 
that the northward flow of thermocline and intermediate waters supplying the source waters for the North Atlantic deep water formation is overall saltier than the resulting North Atlantic Deep Waters that return southward at $24^{\circ} \mathrm{S}$.

\section{Sensitivity to the size of the Ekman transport and Brazil Current transport}

The Ekman transport for February-March 1983 and 2009 was abnormally high at 4.6 Sv. The average seasonal cycle in Ekman transport at $24^{\circ} \mathrm{S}$ has an amplitude of $0.7 \mathrm{~Sv}$ about an annual average transport of $3.3 \mathrm{~Sv}$. The interannual variability in annual average Ekman transport from 1980 to 2010 has a range of $1.2 \mathrm{~Sv}$ between 2.8 and $4.0 \mathrm{~Sv}$. Estimates of Brazil Current transport near $23^{\circ} \mathrm{S}$ to $24^{\circ} \mathrm{S}$ have varied from $4.1 \mathrm{~Sv}$ to $13.2 \mathrm{~Sv}$ (Garfield, 1990 reproduced by Campos et al., 1995; Zemba, 1991). To understand how sensitive the overturning and heat and freshwater transports are to different Ekman and Brazil Current transports, we made alternative estimates of the 1983 and 2009 circulations using changed Ekman and Brazil Current transports. For Ekman transport we made estimates of the circulation using the annual average Ekman transport of $3.3 \mathrm{~Sv}$ rather than the February-March Ekman transport of 4.6 Sv; and for Brazil Current, we made estimates of the circulation after changing both the 1983 and 2009 Brazil Current transports by adding or subtracting northward velocities in the western boundary current region to reduce the 1983 Brazil Current transport by $2.3 \mathrm{~Sv}$ to $10 \mathrm{~Sv}$ or to increase the 2009 Brazil Current transport by $1.3 \mathrm{~Sv}$ to $6.2 \mathrm{~Sv}$.

Reducing the southward Ekman transport by $1.3 \mathrm{~Sv}$ to its annual average value of $3.3 \mathrm{~Sv}$ for both the 1983 and 2009 sections reduces the overturning by $1 \mathrm{~Sv}$, increases the northward heat transport by $0.11 \mathrm{PW}$, increases the southward Mov by $0.06 \mathrm{~Sv}$ (making Mov even more negative) and reduces the net evaporation over the Atlantic basin north of $24^{\circ} \mathrm{S}$ by $0.06 \mathrm{~Sv}$. All these changes are as expected when one reduces the southward flow of warm, salty surface waters. Given the range in seasonal and interrannual Ekman transports, these changes in overturning, heat transport, Mov and evaporation represent the sensitivity of the circulation to the range of realistically varying Ekman transport.

In terms of changing the Brazil Current transport, we modify the velocities only in the western boundary region of each section where there is southward flow. We do not change the width or depth of the Current, only modifying its strength. For the 1983 section we add northward velocity to reduce the transport from $12.3 \mathrm{~Sv}$ to $10 \mathrm{~Sv}$; for the 2009 section we add southward velocity to increase the Brazil Current transport from $4.9 \mathrm{~Sv}$ to $6.1 \mathrm{~Sv}$. The sign of the resulting changes in overturning, heat and freshwater transports are consistent for the two sections. On average, a $2 \mathrm{~Sv}$ increase in southward Brazil Current reduces the overturning by $1.6 \mathrm{~Sv}$, decreases the northward heat transport by $0.094 \mathrm{PW}$, reduces the southward Mov by $0.011 \mathrm{~Sv}$ and increases the net evaporation over the Atlantic basin north of $24^{\circ} \mathrm{S}$ by $0.024 \mathrm{~Sv}$. Again, such changes are as expected when one increases the southward flow of warm, salty waters in the western boundary current. Multiplying these sensitivities by the $7.4 \mathrm{~Sv}$ difference between the Brazil Current transports of $12.3 \mathrm{~Sv}$ in 1983 and $4.9 \mathrm{~Sv}$ in 2009 effectively accounts for the differences in overturning, heat 
transport, Mov and net evaporation estimated for the two sections in Table 1. Thus we conclude that the differing strength of the Brazil Current between 1983 and 2009 is the primary reason for the differences in overturning, Mov and heat and freshwater transports for the two sections analysed here.

\section{Brazil Current}

Little is known about the temporal variability in the structure and transport of the Brazil Current. As stated above, historical estimates of Brazil Current transport near $23^{\circ} \mathrm{S}$ to $24^{\circ} \mathrm{S}$ have varied from $4.1 \mathrm{~Sv}$ to $13.2 \mathrm{~Sv}$ with the consensus being that the average is 9 to $11 \mathrm{~Sv}$ with no apparent seasonal variability (Stramma, 1989). Here we have considered two sections that yield Brazil Current transports near the extremes of historical estimates: 4.9 Sv for the 2009 James Cook section and 12.3 Sv for the 1983 Oceanus section. Thus the estimates we have made for the overturning circulation, heat and freshwater transports and Mov salt transport may represent maximum and minimum values of Brazil Current transport. As a result of uncertainty in Brazil Current transport, we are uncertain whether the overturning is $21.5 \mathrm{~Sv}$ (2009) or $16.5 \mathrm{~Sv}$ (1983); whether the northward heat transport is $0.68 \mathrm{PW}$ (2009) or $0.38 \mathrm{PW}$ (1983); whether the net evaporation required over the Atlantic basin between $24^{\circ} \mathrm{S}$ and Bering Straits is $0.04 \mathrm{~Sv}$ (2009) or $0.17 \mathrm{~Sv}$ (1983); and whether the Mov salinity transport is $-0.13 \mathrm{~Sv}$ (2009) or $-0.09 \mathrm{~Sv}$ (1983). Within these extremes, we are certain that the heat transport is northward, that the net evaporation over the Atlantic basin is small, much smaller than implied by hydrological estimates (Wijffels et al., 1992), and that the salinity flux associated with the overturning circulation transports freshwater southward out of the Atlantic basin. To narrow the range in such estimates, observations of the annual mean size and structure of the Brazil Current and of its temporal variability have highest priority. It would also be useful to quantify the variability in the structure of the mid-ocean circulation either with eastern and western boundary mooring as at $26^{\circ} \mathrm{N}$ (Cunningham et al., 2007) or with suitable Argo profiles near the eastern and western boundaries. With well-defined values for the Brazil Current transport and mid-ocean circulation, we could define the circulation across the entire $24^{\circ} \mathrm{S}$ section to reflect the time-averaged circulation and its temporal variability rather than the snapshot pictures gained here from individual hydrographic sections.

Acknowledgments. The $24^{\circ} \mathrm{S}$ transatlantic hydrographic section was made as part of the UK strategic research programme Oceans2025. The analysis presented here was supported by the Natural Environment Research Council as part of the Rapid-WATCH project to monitor the Atlantic meridional overturning circulation under grants NER/T/S/2002/00481 and NE/G00787X/1.

\section{REFERENCES}

Baumgartner, A. and E. Reichel. 1975. The World Water Balance: Mean Annual Global, Continental and Maritime Precipitation, Elsevier, Amsterdam, 179 pp.

Beal, L. M., W. P. M. de Ruijter, A. Biastoch, R. Zahn and SCOR/WCRP/IAPSO Working Group 136. 2011. On the role of the Agulhas system in ocean circulation and climate. Nature, 472, 429-436. 
Biastoch, A., C. W. Boning and J. R. E. Lutjeharms. 2008. Agulhas leakage dynamics affects decadal variability in Atlantic overturning circulation, Nature, 456, 489-492.

Bryden, H. L. and S. Imawaki. 2001. Ocean heat transport, in Ocean Circulation and Climate, G. Siedler, J. Church and J. Gould, eds., Academic Press, 455-474.

Bryden, H. L., D. Roemmich and J. Church. 1991. Ocean heat transport across $24^{\circ} \mathrm{N}$ in the Pacific. Deep-Sea Res., 38, 297-324.

Campos, E. J. D., J. E. Goncalves and Y. Ikeda. 1995. Water mass characteristics and geostrophic circulation in the South Brazil Bight: Summer of 1991. J. Geophys. Res., 100, 18537-18550.

Cunningham, S. A., T. Kanzow, D. Rayner, M. O. Baringer, W. E. Johns, J. Marotzke, H. R. Longworth, E. M. Grant, J. J.-M. Hirschi, L. M. Beal, C. S. Meinen and H. L. Bryden. 2007. Temporal variability of the Atlantic meridional overturning circulation at $26.5^{\circ} \mathrm{N}$. Science, 317 , 935-938.

Dijkstra, H. A. 2007. Characterization of the multiple equilibria regime in a global ocean model. Tellus, 59A, 695-705.

Drijfhout, S. S., S. L. Weber and E. van der Swaluw. 2011. The stability of the MOC as diagnosed from model projections for pre-industrial, present, and future climates. Climate Dyn., 36, 989-1003.

Garfield, N., III. 1990. The Brazil Current at subtropical latitudes, Ph.D. Thesis, University of Rhode Island, Kingston, $121 \mathrm{pp}$.

IOC, SCOR and IAPSO. 2010. The international thermodynamic equation of seawater-2010: Calculation and use of thermodynamic properties. Intergovernmental Oceanographic Commission, Manuals and Guides No 56, 196 pp.

Johns, W. E., M. O. Baringer, L. M. Beal, S. A. Cunningham, T. Kanzow, H. L. Bryden, J. J. M. Hirschi, J. Marotzke, C. S. Meinen, B. Shaw and R. Curry. 2011. Continuous array-based estimates of Atlantic Ocean heat transport at $26.5^{\circ}$ N. J. Climate, 24, 2429-2449.

King, B. A. and D. R. C. Hamersley, eds. 2010. RSS James Cook Cruise JC032, 07 Mar-21 Apr 2009: Hydrographic sections across the Brazil Current and at $24^{\circ} \mathrm{S}$ in the Atlantic. National Oceanography Centre Southampton Cruise Report 48, 173 pp.

Marsh, R., W. Hazeleger, A. Yool and E. Rohling. 2007. Stability of the thermohaline circulation under millennial CO2 forcing and two alternative controls on Atlantic salinity. Geophys. Res. Lett., 34, L3605.

McCarthy, G., E. McDonagh and B. King. 2011. Decadal variability of thermocline and intermediate waters at $24^{\circ} \mathrm{S}$ in the South Atlantic. J. Phys. Oceanogr., 41, 157-165.

McCartney, M. S. and M. E. Woodgate-Jones. 1991. A deep-reaching anticyclonic eddy in the subtropical gyre of the eastern South Atlantic Ocean. Deep-Sea Res., 38 (Suppl.), S411-S443.

McDonagh, E. L and B. A. King. 2005. Oceanic fluxes in the South Atlantic. J. Phys. Oceanogr., 35, $109-122$.

Peeters, F. J. C., R. Acheson, G.-J. A. Brummer, W. P. M. de Ruijter, R. R. Schneider, G. M. Ganssen, E. Ufkes and D. Kroon. 2004. Vigorous exchange between the Indian and Atlantic Oceans at the end of the past five glacial periods. Nature, 430, 661-665.

Rahmstorf, S. 1996. On the freshwater forcing and transport of the Atlantic thermohaline circulation. Climate Dyn., 12, 799-811.

Saunders, P. M. and B. A. King. 1995. Oceanic fluxes on the WOCE A11 section. J. Phys. Oceanogr., 25, 1942-1958.

Stramma, L. 1989. The Brazil Current south of 23S. Deep-Sea Res., 36, 639-646.

UNESCO. 1981. The Practical Salinity Scale 1978 and the International Equation of State of Seawater 1980, UNESCO Technical Papers in Marine Science 36, 25 pp.

Warren, B. A. and K. G. Speer. 1991. Deep circulation in the eastern South Atlantic Ocean. Deep-Sea Res., 38 (Suppl.), S281-S322. 
Weijer, W., W. P. M. de Ruijter, H. A. Dijkstra and P. J. Van Leeuwen. 1999. Impact of interbasin exchange on the Atlantic overturning circulation. J. Phys. Oceanogr., 29, 2266-2284.

Wijffels, S., E. Firing and H. Bryden. 1994. Direct observations of the Ekman balance at $10^{\circ} \mathrm{N}$ in the Pacific. J. Phys. Oceanogr., 24, 1666-1679.

Wijffels, S., R., Schmitt, H. Bryden and A. Stigebrandt. 1992. On the transport of freshwater by the oceans. J. Phys. Oceanogr., 22, 155-162.

Zemba, J. C. 1991. The structure and transport of the Brazil Current between $27^{\circ}$ and $36^{\circ}$ South, Ph.D. Thesis, Woods Hole Oceanographic Institution-Massachusetts Institute of Technology Joint Program, WHOI Technical Report 91-37, Woods Hole Massachusetts, 160 pp.

Received: 17 March, 2011; revised: 31 August, 2011. 